\title{
Landscape as Experience: An Integration of Senses and Soul
}

\author{
Barbara M Cheshire
}

\author{
Barbara Cheshire Studio
}

\begin{abstract}
The extent to which experiential and spiritual perceptions of the senses - in response to an event or place can be transformed into visual art as a vehicle of communication, is yet to be understood. This paper, therefore, examines if a cohesive physical representation from a structured, visual art system is capable of developing a Christian experiential visual language that communicates a sensorial and transcendental experience of place; in this case North Queensland. Commentary on the physical representation subsequently tests if a holistic integration of one human's sensorial response to place and an internal experience of Christian spirituality in that place can be communicated to the viewer through an art exhibition. The analysis found evidence to suggest that a spiritual essence of place - seeing place from inside and out - could be communicated and experienced by viewers of the exhibition.
\end{abstract}

$\mathrm{I}_{\mathrm{i}}^{\mathrm{n}}$ n the literature of art, communicating the way in which physical sensorial perceptions cohere into a spiritual experiential response to place in north Queensland, does not appear to be researched and documented. Although varied environments in the north Queensland region have attracted spiritual painters since white settlement, these representations range from the literal to the symbolic to the abstract and are shown to be mediated through the ideologies, assumptions and belief systems of the artists. However, to understand how spiritual experiential art from sitespecific places can be developed into a vehicle of communication calls for a different form of mediation. As a result, for the purpose of this research, a structured, experiential process was examined to interpret and render the holistic experience from spiritual and sensory perceptions.

\section{Underpinning research}

A review of historical aspects that address the separate topics of perception theory, visual language and spiritual visual language and place was undertaken. For instance, perception is seen as involving the organization, identification and interpretation of all forms of sensory information to represent and understand the world (Saks and Johns 2011); visual language is seen as a form of communication based on images (Giovannelli 2011). Indeed, art historian Nicholas Mirzoeff (1998) contends that visual language "is not just a part of your everyday life, it is your everyday life" (p.3). Spiritual visual language and place is a vast theme that has been represented in many faiths across the world for thousands of years. When a selection of spiritual and religious art was examined, it became obvious that the process varied depending on cultural differences and traditions. Each approach explored creative forms and symbols in which humanity has communicated a spiritual visual language of a numinous experience of the world. An examination of a brief history of spiritual art in Australia and then specifically north Queensland was also assessed as part of the underpinning research. 
Although these insights into the intellectual dynamism, creativity and imagination of spiritual art deepened and underpinned some of the creative process of art explored, many questions remained unanswered for me. A new creative process was therefore required to interpret a natural aesthetic to engage and signify several aspects to the viewer: the first, a Christian spiritual experience of place; the second, personal and intimate feelings and beliefs which affirm and give meaning; and the third, a contribution to self-knowledge through the viewers experience of the art and a particular way of knowing.

\section{Methodology}

The ensuing methodology to translate a natural structured system for a Christian Experiential Visual Language (CEVL) involved four different sites from which four suites of artworks were developed through nine exploratory steps (see Figure 1 below). 


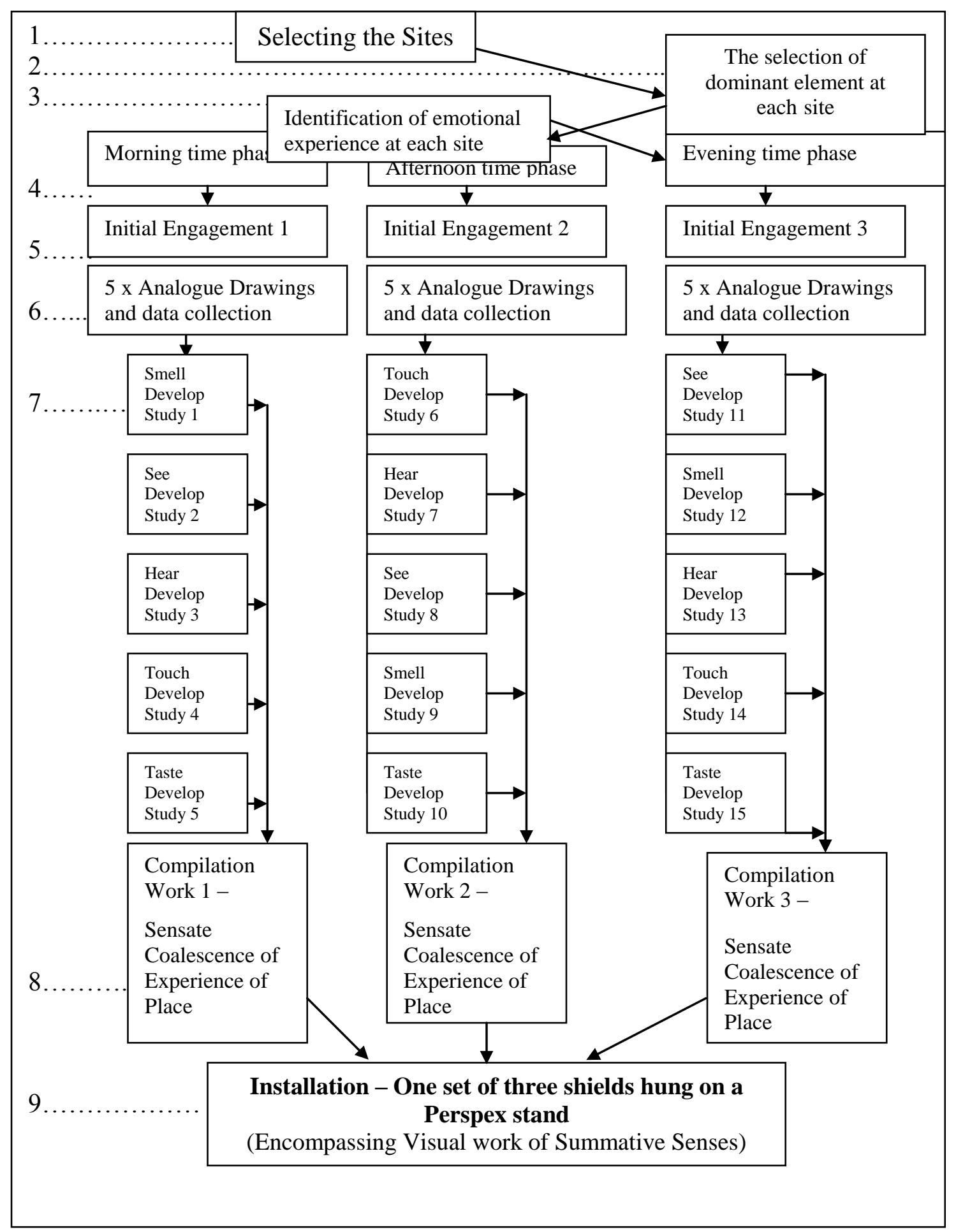

Figure 1 A visualization of the creative process and methodology demonstrating different order of sensorial experiential strength 
These four north Queensland sites, (see Figure 2 below), were monitored over several years. The sites were selected for detailed study from a preliminary group of 8 sites. The eight sites were selected because they had previously elicited a personal spiritual connection that was deeply significant. In order to reduce the number of sites to four, which was determined as the appropriate number for the creative work, spiritual responses to these sites were categorised using the following terms: security, stillness/peace and spiritual freedom.

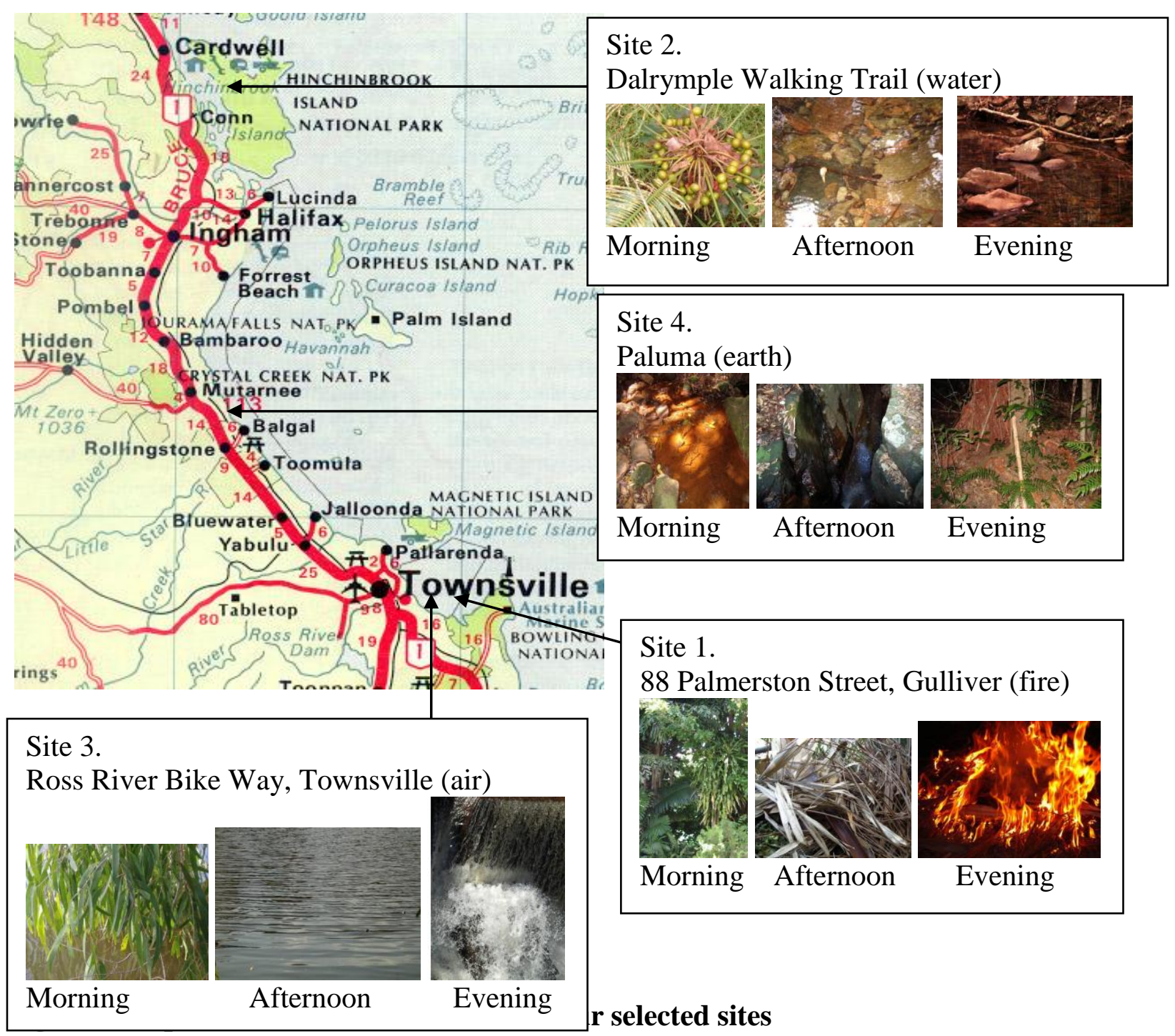

In order to record the strength and type of the response, a psychological process documented in Hersen, Kazdin, and Bellack (1991) for identifying emotions was applied. A rating scale of 1 10 was also used to measure my spiritual resonance. One equalled no spiritual resonance and 10 equalled the highest spiritual resonance. The examination and documentation of each sitespecific place evolved through my lived experiences.

Two phases, an objective phase and portraying the feeling, provided an overarching view of the methodology to portray a Christian spiritual aesthetic as complete experience, (see Table 1 below). Each of the specific stages of the process were considered separately to allow for the 
analysis of the ways in which particular steps trigger a spiritual mindset that excites a personal response to a particular site. After that, to develop a CEVL, the physical and the spiritual were interwoven in order to reproduce the entire experience of place

\section{Table 1}

Portraying a Christian spiritual aesthetic as complete experience

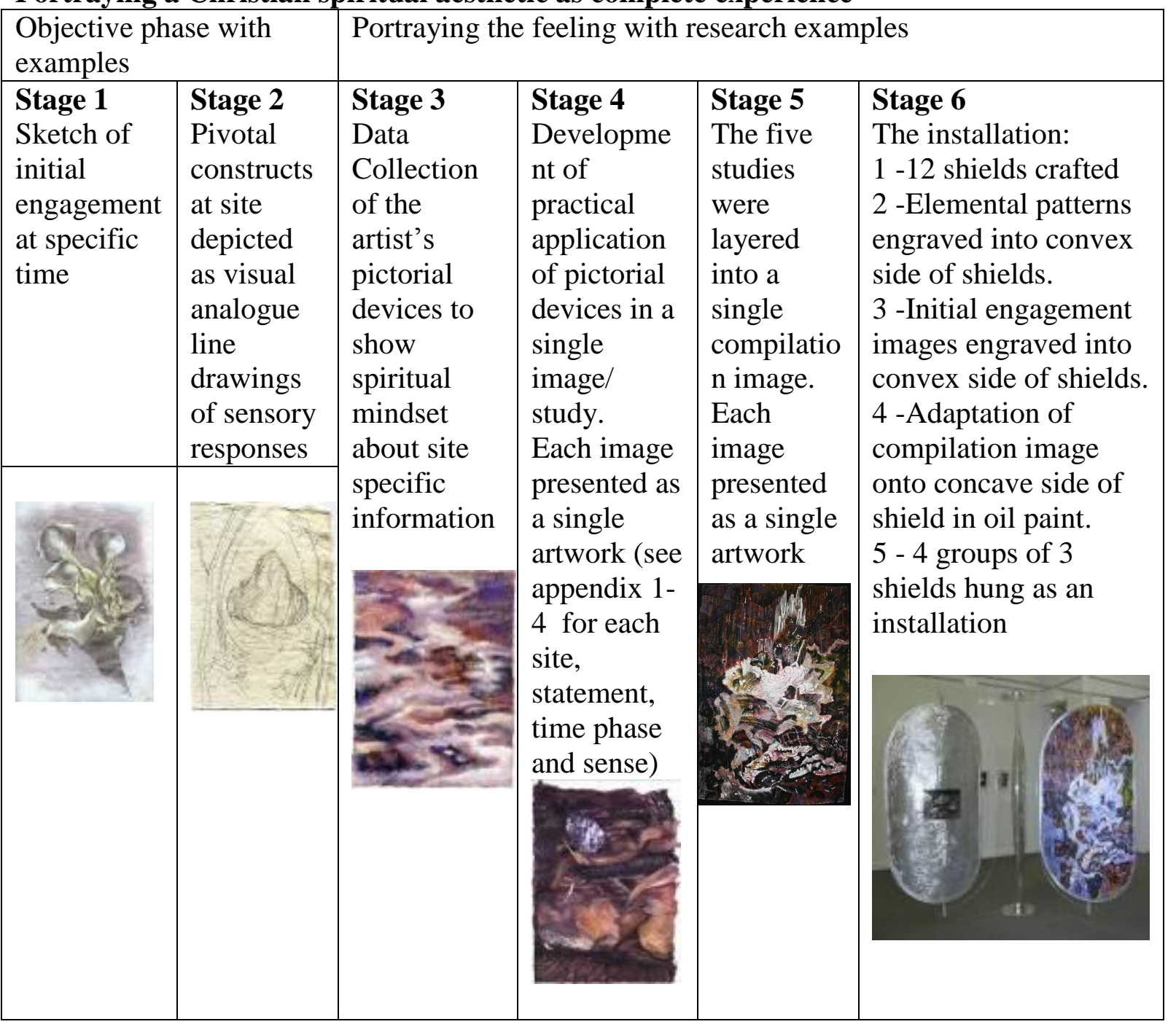

\section{Defining the dominant element}

The first exploratory steps involving the five sensorial responses were grounded in the four elements of fire, water, air and earth at a particular site, (see Table 2 below). The elements are connected to specific sites separately because a dominance of one particular element was experienced more strongly than any of the other three. Fire was dominant at Site 1: 88 Palmerston Street; Water at Site 2: the Dalrymple Gap Walking Trail; Air at Site 3: the Ross River bike track; and Earth at Site 4: Paluma. These elements were examined not just through the material senses but through a combination of their experiential, factual and symbolic encounters. 
Table 2 - Elements and sites

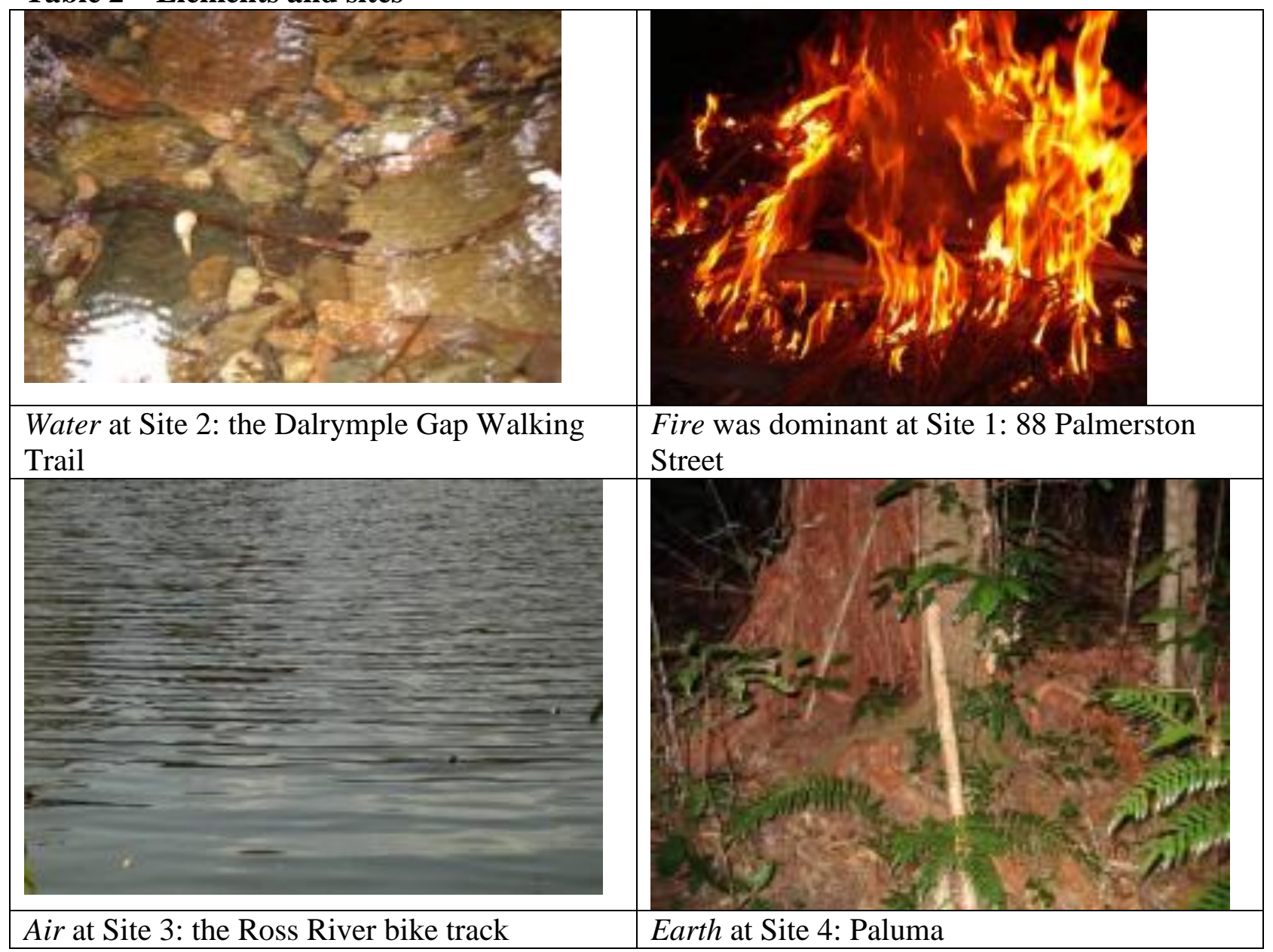

\section{Time phases}

The methodology attempts to depict my personal experience but that personal experience varied depending on when a site was visited. Hence, if a CEVL is to be holistic, it needs to show experiences at several different times. To depict only one time is to take a slice and pretend it is the whole of reality. Therefore the four sites were examined at morning, afternoon and evening over a period of years. My aim was to express, in the final compositions, a sense of the underlying oneness of time, earth, God and humanity which I experienced at each particular site. Thus, I deemed it helpful to bring into each compilation the same site observed at different times of the day and year in order to reflect the seasonal variations as well as my subjective sensorial responses to those fluctuations and changes. In this way the final composition could encompass the most diverse sensory responses at each site. Therefore, layering different sensate 'snapshots' of the one site could increase the possibility of visually expressing a holistic spiritual experience.

The later steps in the research involved compiling the data from each site then representing the sensate experiences in a visual form. Each visual form intended to convey a sense of the emotional and spiritual responses to each site, element and time phase. These components were 
chosen because they express the sum of my sensory, emotional and spiritual experience of a place.

\section{Stage one: The initial engagement}

The initial engagement at each site, (see Plate 1 below), involved a sketch of a physical element that first attracted my attention. The sketch, therefore, was an image of the physical, external world that cultivated my internal intention to choose an attitude of trust and acceptance of a Divine presence and action in nature. 


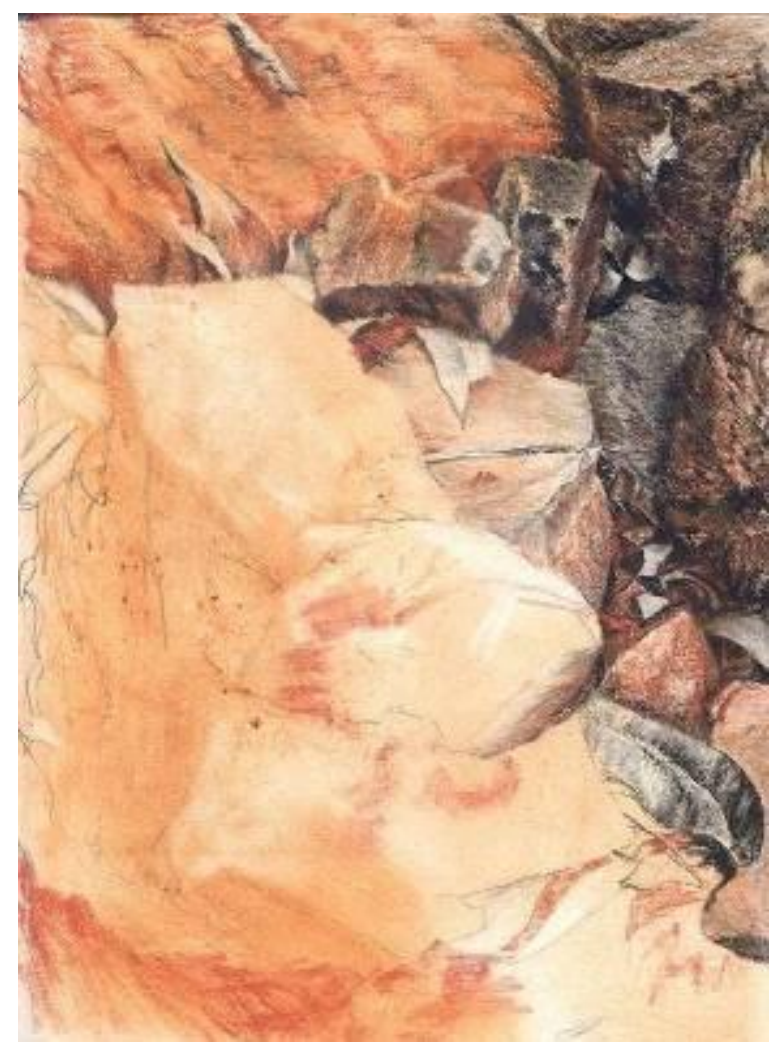

\section{Plate 1}

Earth Afternoon - Initial Engagement, 2004

Dirt from site, charcoal pencil and Conte

$20 \times 28 \mathrm{~cm}$

(Sketchbook 1 - Page 10)

\section{Documentation of sensorial response to each site}

The next phase of the research, the data collection, was the written, verbal description of each sensorial response recorded in my journal for further analysis. The process captured, as accurately as possible, the elements which made up the experience. The information was noted as soon as the analogue drawing was completed and while the same individual sense response was being experienced. The written information corresponded to the analogue drawing so that, when each study was developed from the line drawing at a later date, I could be reminded of the 'truth' of that early experience (see Table 3 below). 
Table 3

Site 2- Data Information - Earth Morning - Studies of Senses 16-20 in order of Significance

\begin{tabular}{|c|c|c|c|c|c|}
\hline 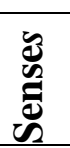 & $\begin{array}{l}1 \\
\text { Seeing }\end{array}$ & $\begin{array}{l}2 \\
\text { Smelling }\end{array}$ & $\begin{array}{l}\mathbf{3} \\
\text { Touching }\end{array}$ & $\begin{array}{l}4 \\
\text { Hearing }\end{array}$ & $\begin{array}{l}5 \\
\text { Tasting }\end{array}$ \\
\hline 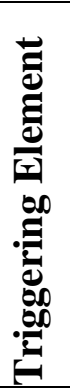 & $\begin{array}{l}\text { The cave like } \\
\text { environment is } \\
\text { teaming with a } \\
\text { constant gentle } \\
\text { movement of } \\
\text { life }\end{array}$ & $\begin{array}{l}\text { Sweet gentle } \\
\text { smells from the } \\
\text { cool, } \\
\text { undisturbed } \\
\text { environment } \\
\text { drift over the } \\
\text { earthy smell of } \\
\text { the undergrowth }\end{array}$ & $\begin{array}{l}\text { An innate } \\
\text { energy } \\
\text { emanates in the } \\
\text { location through } \\
\text { many diverse } \\
\text { textures }\end{array}$ & $\begin{array}{l}\text { Musical } \\
\text { energies of } \\
\text { repetitious } \\
\text { birdsong echo } \\
\text { like beats of life }\end{array}$ & $\begin{array}{l}\text { There is } \\
\text { contrast } \\
\text { between the } \\
\text { cool taste of the } \\
\text { air and the } \\
\text { warm sultry } \\
\text { spicy tastes } \\
\text { from vegetation }\end{array}$ \\
\hline 遶 & $\begin{array}{l}\text { The incredible } \\
\text { feeling of being } \\
\text { nurtured is } \\
\text { experienced } \\
\text { while sitting } \\
\text { quietly in the } \\
\text { environmental } \\
\text { sanctuary by } \\
\text { the creek }\end{array}$ & $\begin{array}{l}\text { The cool } \\
\text { morning breeze } \\
\text { lifts and layers } \\
\text { fresh, gentle } \\
\text { smells in the } \\
\text { midst of the } \\
\text { primary damp } \\
\text { earthy smell }\end{array}$ & $\begin{array}{l}\text { Patches of dead } \\
\text { leaves, smooth } \\
\text { green moss, } \\
\text { rocks and red } \\
\text { earthy soil form } \\
\text { the textures in } \\
\text { the damp } \\
\text { surroundings }\end{array}$ & $\begin{array}{l}\text { A remarkable } \\
\text { silence that is } \\
\text { never really } \\
\text { silent is broken } \\
\text { by the human } \\
\text { heart beat and } \\
\text { the sound of } \\
\text { breathing. The } \\
\text { musical and } \\
\text { repetitious } \\
\text { chorus of } \\
\text { birdsong, the } \\
\text { loud squawk of } \\
\text { a cockatoo and } \\
\text { the buzz of } \\
\text { mosquitoes now } \\
\text { add to the beat } \\
\text { of life that } \\
\text { stretches across } \\
\text { the stillness }\end{array}$ & $\begin{array}{l}\text { Strong sweet } \\
\text { pungent smells } \\
\text { of undergrowth } \\
\text { result in an } \\
\text { underpinning } \\
\text { earthy, spicy } \\
\text { taste } \\
\text { The clean taste } \\
\text { of fresh cold air } \\
\text { is punctuated by } \\
\text { spicy tastes as it } \\
\text { is sucked into } \\
\text { the lungs }\end{array}$ \\
\hline & 16 & 17 & 18 & 19 anyey & 20 \\
\hline 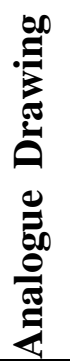 & & & & & \\
\hline
\end{tabular}


Table 3 continued

Site 2- Data Information - Earth Morning - Studies of Senses 16-20 in order of Significance

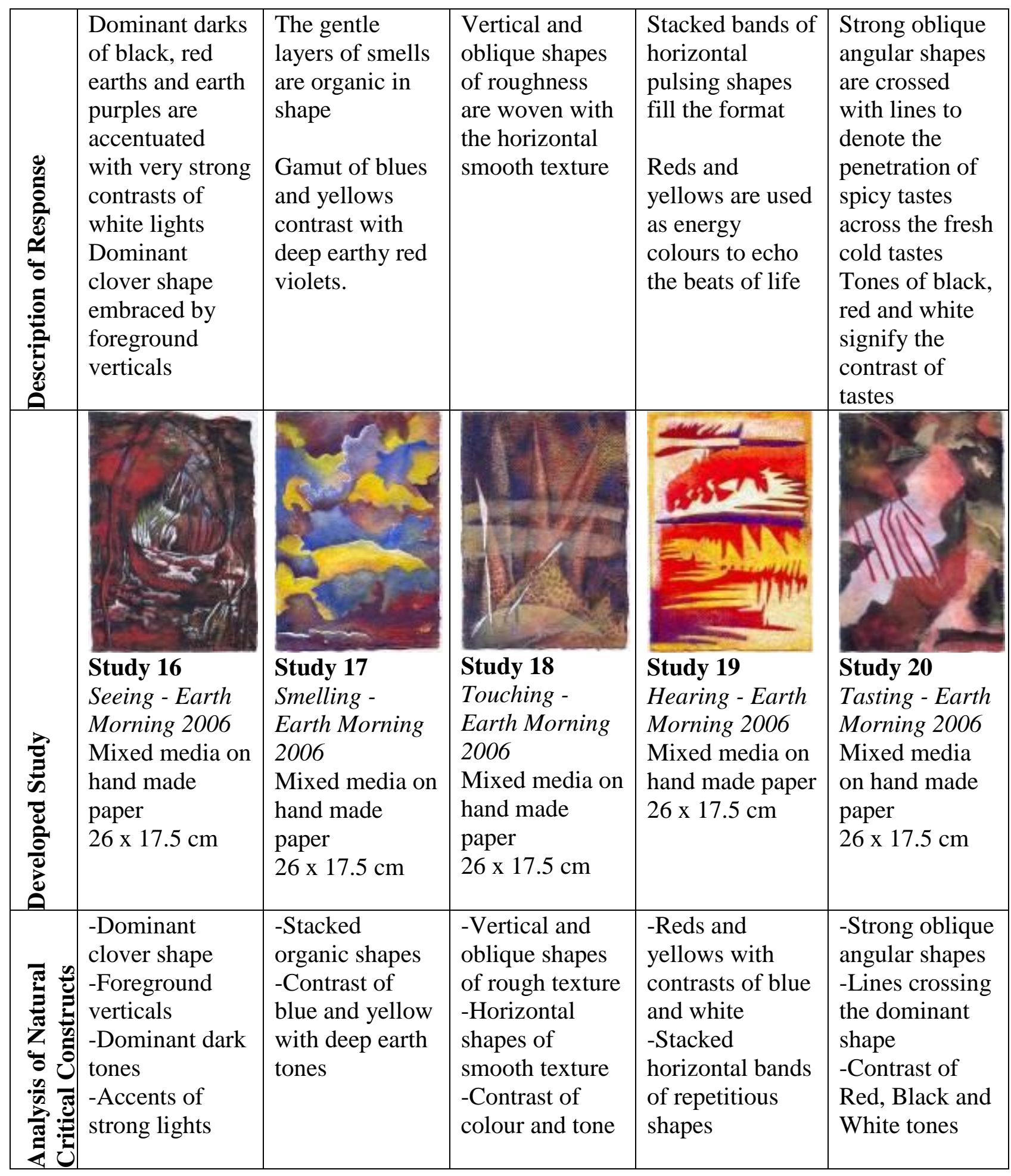

To communicate a holistic response to site through visual art required techniques that corresponded with the multilayered nature of my experience. Many layering techniques were 
applied during the creative process. The final installation used both individual layering as well as combinations of techniques. All the applications of dry and wet layering formed ranges of colour values and relationships between forms and their contexts which helped to further express the notion of holistic experience.

\section{Compilation painting}

The 60 artworks were then compiled into 12 compilation paintings, (see Table 4 below), each developed from five studies of a specific time frame and place. However, the layering process often cancelled out some aspect of technique which created a different visual effect and this reflects/reinforces what happens for us as observers. The compilation thus attempted to depict a holistic sensorial response to a specific site at a specific time. This process was a stage towards 'holistic attention' (Armstrong 2000) required for the shields.

\section{Table 4}

\section{Layered analogue drawings and Developed compilation painting}

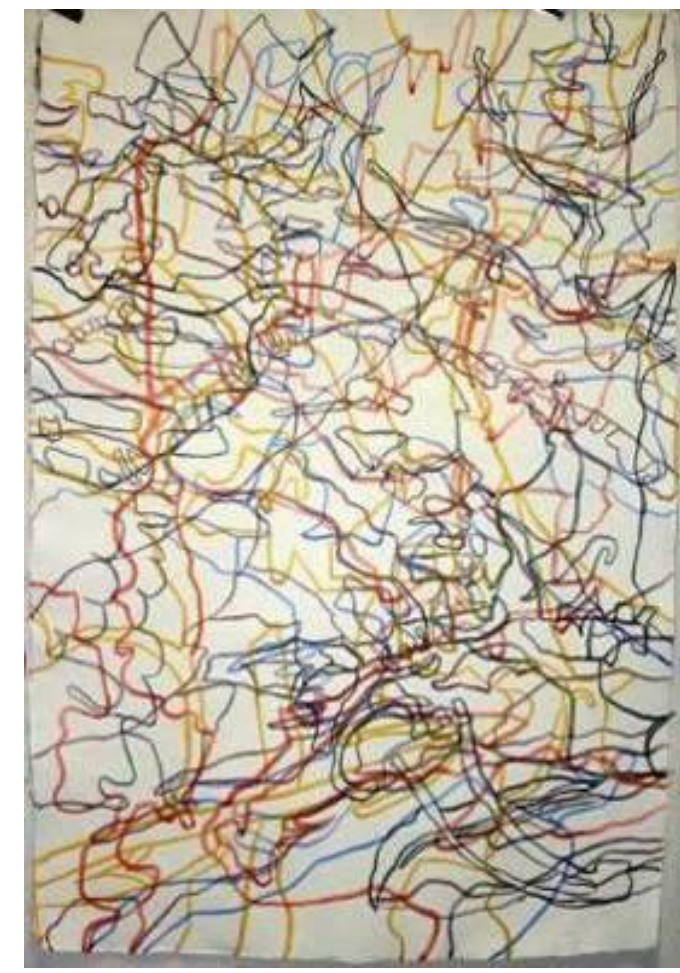

Water Evening - 5 Layered Analogue Drawings for Compilation Work

Gouache

104 x $69 \mathrm{~cm}$

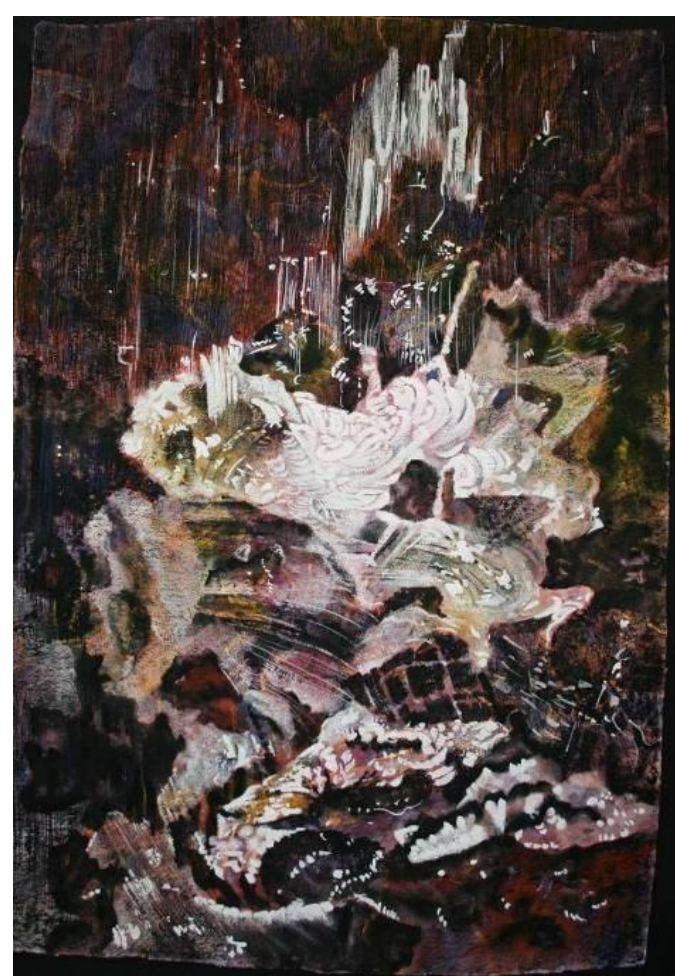

Water Evening Compilation 2008 Mixed media on hand made paper $104 \times 69 \mathrm{~cm}$

\section{Shields}

The physical shields, (see table 5 below), not only represent my exterior life and internal experience and soul at site but also my consciousness of God's design and essence all around and within me. For instance, designs can be seen through my experience of the natural objects that are ground into the convex side on the shield and act as metaphorical windows to the internal soul. 


\section{Table 5}

Site 2- Earth Morning Shield

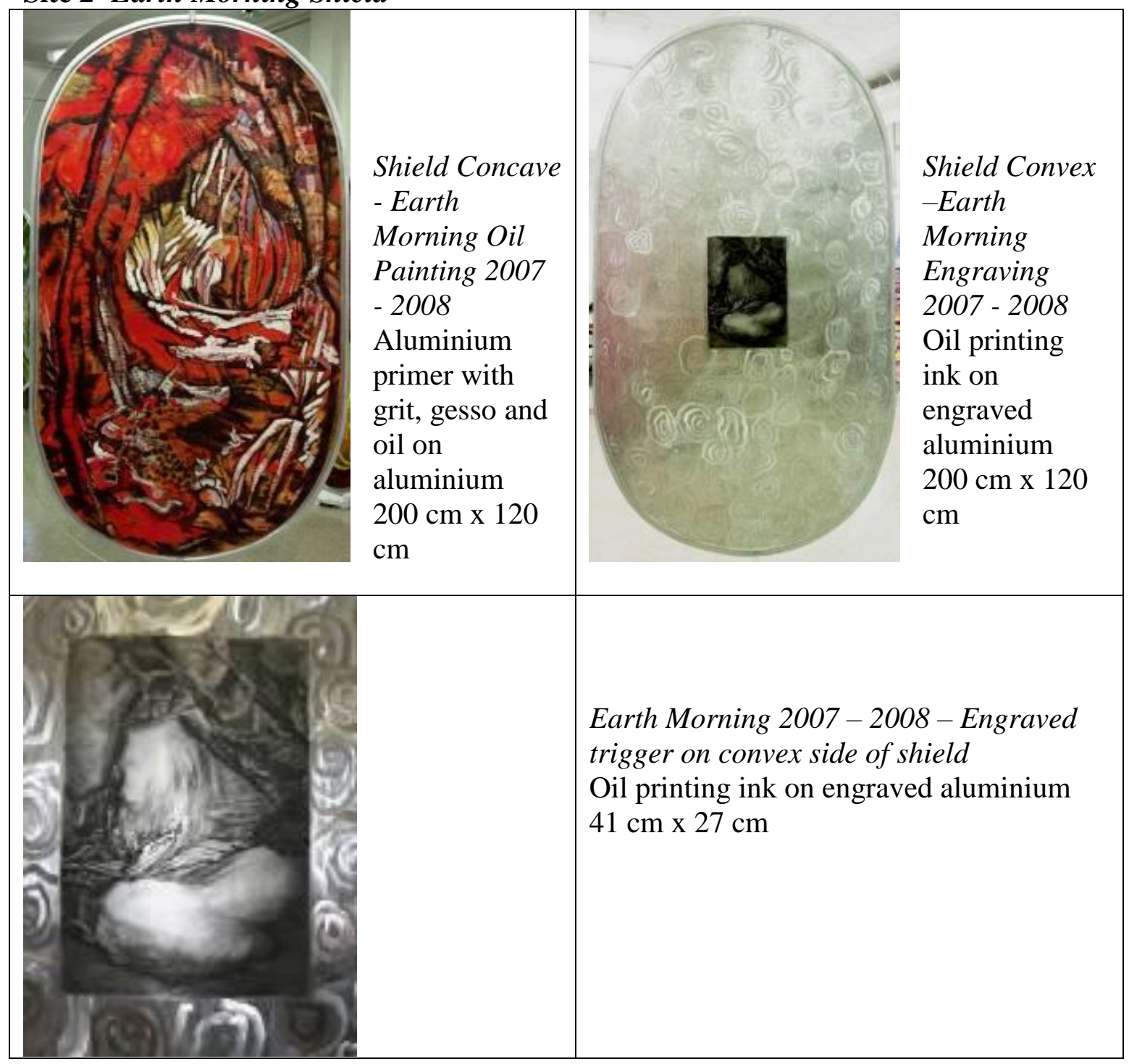

Thus, the oil painting on the concave side of the shield signifies my internal, spiritual and emotional perception of place during one time phase. The paintings offer a total integration of soul with landscape and reinforce the analogy of bringing together two worlds: the transition from the external world to the most central core of spiritual contemplation. The concave side attempts to depict not just an internal phenomenological or sensorial perception but a spiritual experience.

\section{The hanging system for the exhibition}

The hanging system for the installation also had to maintain the integrity of all the artwork and be consistent with the methodology for a CEVL. For instance, the shields needed to be hung so that the viewer could see my outside world on the convex side and my inside world on the concave side: hence, the interwoven combination of circumstance and experience of all senses 
and soul. After many trials Perspex was the material selected for the hanging system, (see Table 6 below) as it met all physical and conceptual requirements. The transparent support for the shields underlined the notion of the invisible but powerful divine support for my human reality; a complex concept of a higher truth symbolised in the context of Christianity.

This Christian spiritual artwork is a metaphor, a symbol of the spiritual experience of place. The CEVL has important function because it provides a method and opportunity for dealing with spiritual experience by communicating through a visual interaction. Thus the viewing, the collective experience within the shields, offers possibilities of transformation and spirituality of place to be truly experienced by others. Through the visible, the previously invisible is made manifest. 
Table 6 Final Design of hanging system for shields

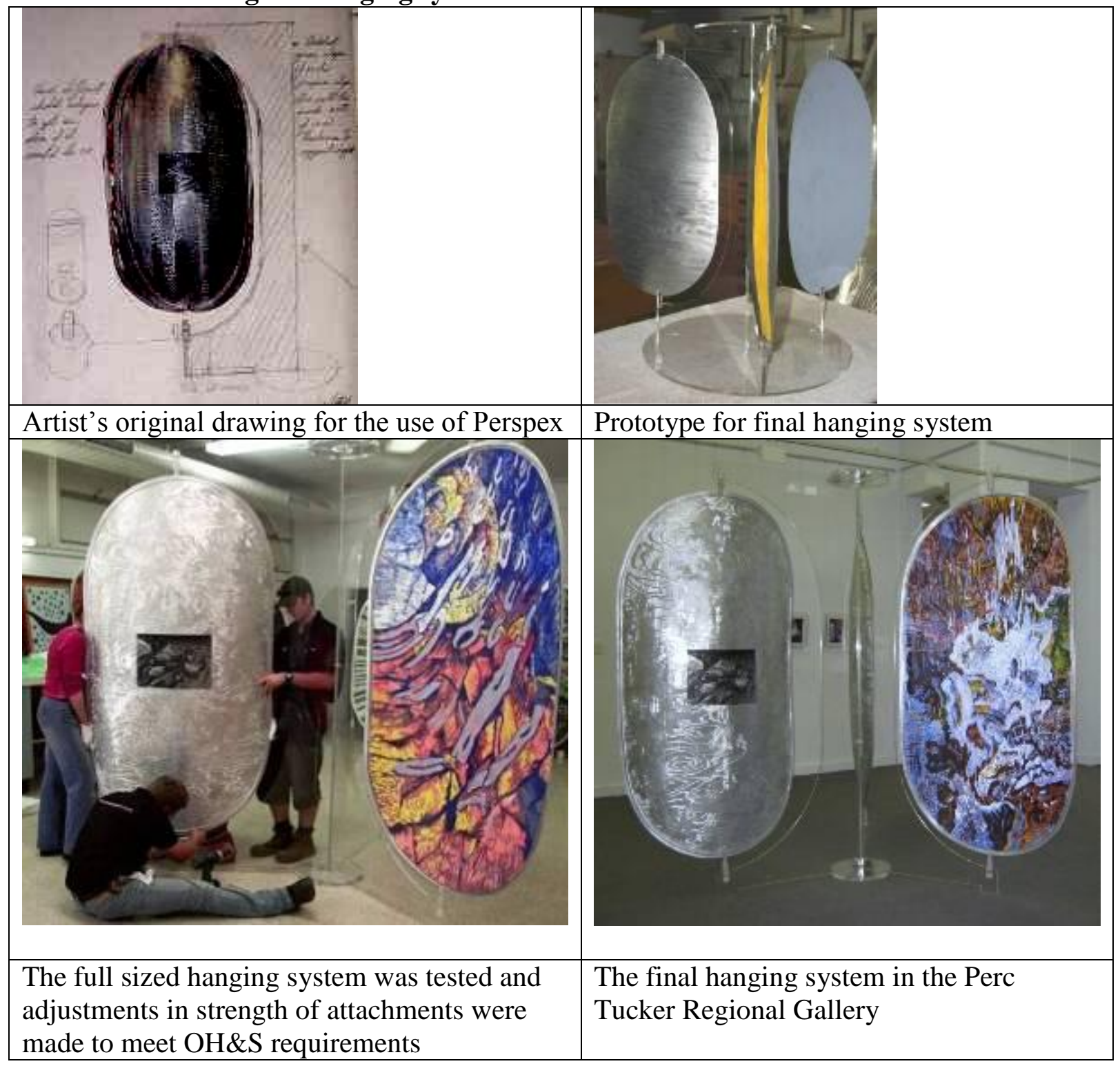

The 96 pieces of artwork in the exhibition, (see Table 7 below), were deliberately positioned to give the viewer a sense of walking into a cathedral. I attempted to evoke this effect for two reasons. First, I have often felt how the magnificence and sense of natural holiness of the rainforest create the sense of being in a sacred space like a cathedral. Second, I wanted the viewer to become aware of the sense of the spiritual and part of that sense of awe and wonder emerges when one is overawed by larger and unexpected environments. The exhibition not only gave the 9,496 viewers a chance to contemplate a recent form of spiritual art but also the chance to reflect on a visual language that links spiritual art, time and place. 
Table 7 Left and right views of installation

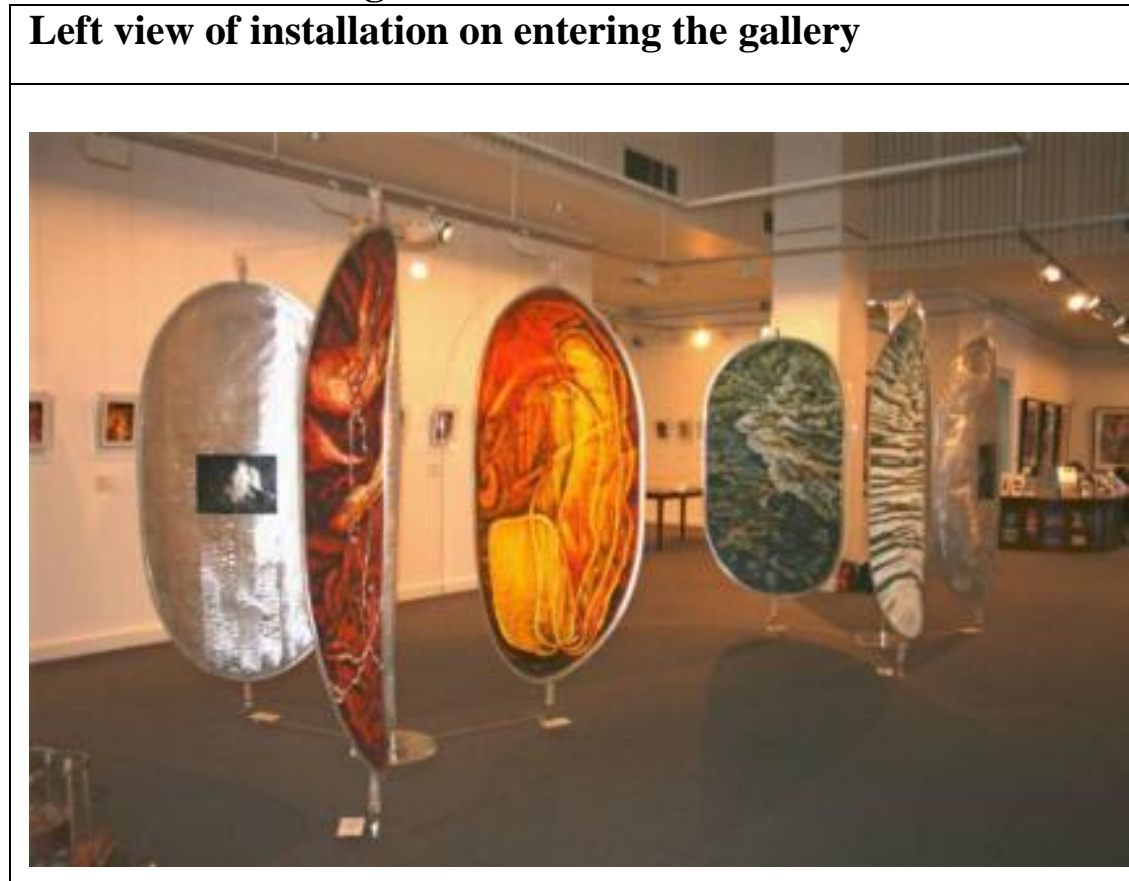

Left side view of the exhibition as you enter the gallery comprising of two sets of shields, Fire and Air, which are surrounded by studies. Compilation work viewed deeply in the background.

\section{Right view of installation on entering the gallery}

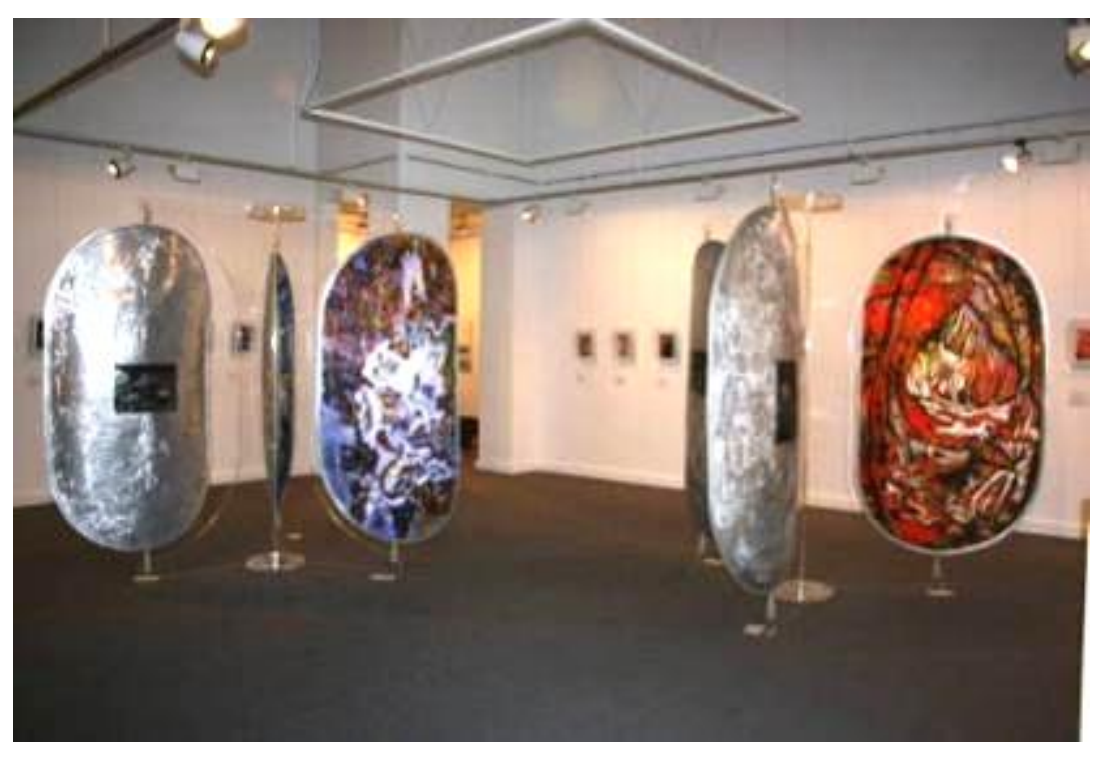

Right side view of the exhibition as you enter the gallery comprising of two sets of shields, Water and Earth, which are surrounded by studies. 
Of central importance to the effect of the exhibition was gauging the reaction to the installation. The viewer's comments that documented experiential responses to the exhibition, revealed how my sensorial and spiritual perceptions were communicated, for example, through commentaries such as 'you touched my soul' and 'you have captured the essence of the spirit'. Samples of 229 comments were analysed to test the effectiveness of the communication, (see Figure 3 ). The comments demonstrated that the exhibition made a positive contribution to the individual as well as the broader human culture.

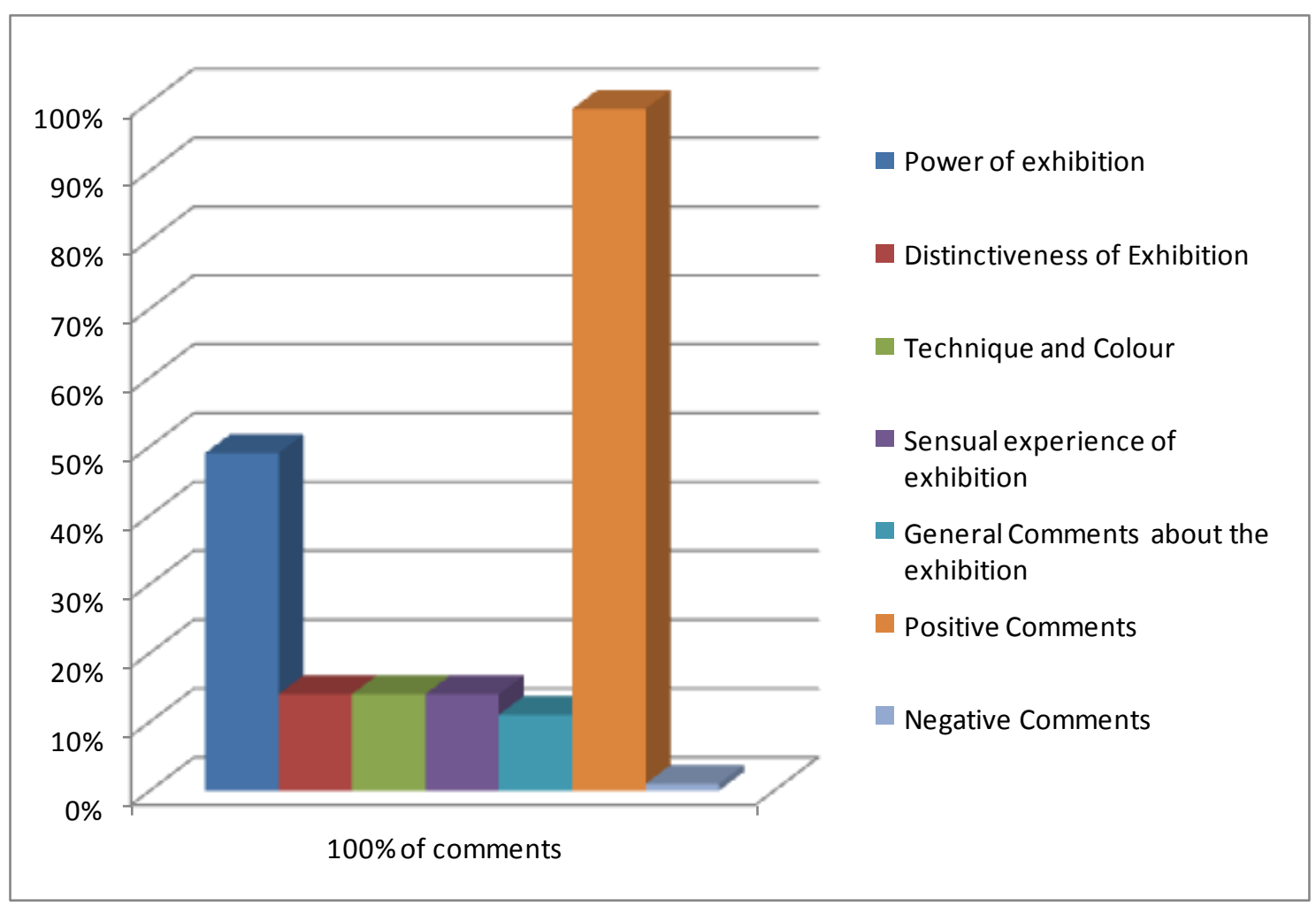

Figure 3 Percentage of visitor comments under each theme

\section{Outcomes}

The study found evidence to suggest that the research aims were realized. A spiritual essence of place could be communicated and experienced by viewers of the exhibition. Further, the documentation of the system in the form of this paper shares the intricate process of one artist's human response to that experience through the data and images of abstract compositions of harmony which reflect the spiritual harmony experienced at place.

The study also contributes to knowledge through five areas:

- $\quad$ The first is a fresh approach to spiritual painting from North Queensland that suggests a new methodology of inquiry into painting;

- $\quad$ The second reintroduces the importance of place through careful observation and description of place in North Queensland through artwork;

- $\quad$ The third reinforces an artistic genre as map-maker of the conscious and spiritual world through a process of disclosure: a process that exposes who I am, what I am and where I am. 
- $\quad$ The fourth contributes to the literature on spiritual art from North Queensland; and - $\quad$ The fifth contributes to art education. When a student inter-relates with themselves regarding the value of place and purpose in life, the process can create self awareness which, in turn develops identity and self esteem. Thus, the methodology is a process of transformation, not only information, which comes from application.

Throughout history there have been many global variations of conceptual engagement to communicate the spiritual through the discipline of painting. The visual logic from this research, however, offers a view that is a map of the interconnected relationship between the whole person, place and divine essence. And further, it offers a view that constitutes an experience of mystery beyond the window of the physical senses, beyond a revealing of the discovery of patterns of order, to a connection with the unknown, silent and spiritual consciousness of the artist, a Divine Essence, and their relationship to this North Queensland landscape through visual art.

\section{Works Cited}

Armstrong, John. The Intimate Philosophy of Art, Harmondsworth: The Penguin Press, 2000. Print

Crane, Tim. "The Problem of Perception", The Stanford Encyclopedia of Philosophy (Spring 2011 Edition), E. N. Zalta ed. 2011. Web. 7 December 2012. http://plato.stanford.edu/archives/spr2011/entries/perception-problem/

Giovannelli, Alessandro. "Goodman's Aesthetics", The Stanford Encyclopedia of Philosophy (Fall 2011 Edition), Edward N. Zalta, ed. 2011. Web 7 January, 2013. http://plato.stanford.edu/archives/fall2011/entries/goodman-aesthetics

Hersen, Michel, Alan E. Kazdin and Alan S. Bellack, eds. The Clinical Psychology Handbook, Second Edition, Australia: Pergamon Press Australia Pty Ltd, 1991. Print

Mirzoeff, Nicholas, ed. The Visual Culture reader, London and New York: Routledge, 1998. Print

Saks, Alan and Gary Johns. "Perception, Attribution, and Judgment of Others", Organizational Behaviour:Understanding and Managing Life at Work Vol. 7, 2011. Web. 7 December 2012. 